\title{
Sources Allocation on Risk Performance of Egyptian Insurance Companies
}

\author{
Salah Mohamed Eladly ${ }^{1}$ \\ ${ }^{1}$ Higher Institute of Advanced Studies, Giza, Egypt \\ Correspondence: Salah Mohamed Eladly, Lecturer, Higher Institute of Advanced Studies, Giza, Egypt.
}

Received: August 16, 2021

Accepted: September 15, $2021 \quad$ Online Published: September 17, 2021

doi:10.5430/jms.v12n3p32

URL: https://doi.org/10.5430/jms.v12n3p32

\begin{abstract}
The main objective of current paper was to investigate the relationship between sources allocations measured by (external sources to total assets- free investment and allocated investment to total assets) on risk performance measured by financial risk (standard deviation of return on equity) business risk (standard deviation of return on assets) using ARDL and GARCH model, using a sample of 19 Egyptian insurance companies over a 21 year period form 1999 - 2019, the findings indicate that There is a significant negative linear relationships between the independent variable in terms of capital structure and assets structure on dependent variable standard deviation of return on equity (Y1) at a Significant level less than (0.05). Also there is a significant positive linear relationship between the independent variable in terms of assets structure and dependent variable standard deviation of return on assets (Y2) at a significant level less than (0.001). with regard to ARCH and GARCH result shows the There is a significant positive effect of the ARCH term, measured as the lag of the squared residual from the mean equation, and the GARCH term, Last period's forecast variance, at a significant level less than (0.05). It means that the high volatility in the conditional variance of standard deviation of return on assets y2. also The sum of the two parameters of: $(\alpha+\beta)$ in the GARCH model $(1,1)$ whether the random error are distributed according to normal distribution approaches the positive one, which indicates that the two conditions of non-negative variance, and the variance is not inflated are satisfied, and that Indication of the continuity of volatility shocks in the standard deviation of return on assets (Y2).
\end{abstract}

Keywords: sources allocation standard deviation of return on asset, standard deviation of return on equity, GARCH

\section{Introduction \& Literature Review}

Sources allocation is used in determining line management compensation in insurance firms depend on return on assets meanwhile the policyholders of insurance companies are concerned about risk aversion based on this complicated relationship this study investigated the relationship between sources allocation and risk performance measured by standard deviation of return on equity and standard deviation of return on asset to cover both of side asset allocation and capital structure

There are various techniques for capital allocation and were applied in insurance industry as following.

The capital asset pricing model - value at risk -Marginal capital allocation proposed by Robert Marten\& Andre Perrold (1993) and regulatory risk - based capital used by US since 1993.

The contribution of this study is to examine relationship between sources allocation and risk performance tomanage, controland mitigate the consequences of the riskperformance in insurance companies in Egypt.

G A Delsing \& et al (2021) they proposed dynamic risk at value measure as a capital allocation method, their found is allocated risk measure is positively homogenous, allocated risk is deterministic whereas marginal risk is determine and the allocated fulfils the full allocated principle. Regarding to comparison with gradient allocation approach is satisfies with dynamic value at risk for capital determined.

Woo-Young Kanga\& Sunil Poshakwale (2019) they developed Return on risk adjusted capital model form single period to multi -period model, the findings indicate that new model return on risk adjusted is significantly improved capital allocation efficiently. 
Shaun Yow \& et al (2007) they presented a value maximization model compared with value at risk model the finding indicates that value maximization model is better than value at risk model for capital allocation where pricing affected by preferences for financial quality and demand elasticity.

Nejat Capar \& et al (2015) they investigated relationship between international diversification on risk performance, the results show that there is insignificant relationship between international diversification on risk performance in $\mathrm{U}$ $\mathrm{S}$ manufacturing firms, while there is a negative significant relationship between marketing assets on risk performance but there is a positive significant relationship between innovation assets on risk performance.

Michael Kalkbrener (2005) this study provide allocation techniques based on derivatives, covariance and expected shortfall the result shows there is not exist linear.

David Blake \& et al (1998) this research provides a systematic analysis of performance managed of portfolio through multi asset classes that found of slow mean reversion in portfolio weight in UK pension funds.

Andrea Rigamonti \& Alex Weissensteiner (2020) that found an inverse U shape relationship between selected risk aversion coefficients of investor and expected utility.

Julita M. Bock (2013) the research presented evidence that German firms used risk management to increase their leverage capacity and risk management to extent a stead of equity capital.

Robert Merton \&Andre F Perold (1993) this research has developed a framework based on risk capital that funded by the firm for analyzing those decision within the principal financial firm to full allocation which has a significant relationship with profitability.

Ines Kahloul \& Slaheddine Hallara (2010)this research exposed that there is negative insignificant relationship between diversification on performance but there is a positive significant relationship between diversification and leverage on risk when it is nonlinearwhereas there is positive insignificant relationship between diversification on size.

Meng-Fen Hsieh \& et al (2015) this research exposed that there is a positive relationship between diversification on risk and returns where is significantly positive with performance but there is a negative relationship between leverage on profitability, regarding to control variables (size. nature algorithm of total assets, nature algorithm of capitalisation, assets growth, nature algorithm of capital, inflation rate and GDP) have statistically significant relationship with diversity.

Stuart M. Turnbull (2000) this study presented an analytical and practical framework that shows the capital allocation depends on covariance of return.

Suleyman Basak\& Dmitry Makarov(2007) this study provides two formulation first one, unique Nash equilibrium to ensuring investment policies, second formulation about manager whose concern relative performance is high significant.

Monica Billio \& Roberto Casarin (2006) applied a Monte Carlo simulation to treat optimal asset allocation problem with shortfall constraints the result shows that correct evaluation of the fattailedness of asset returns is important for the determination of optimal asset allocation.

Michael Sherris (2006) this paper has selected economic valuation model to allocate of capital include three variable accounting the liability risk, the asset risk and solvency the result show to allocate insolvency to line of business based on ranking of outstanding claims payment.

Tomasz R. Bielecki \& et al (2000) this article used the mean- variance efficient frontier to show how a risk sensitive criteria can applied to optimal asset allocation strategy, the result shows that it can be predictability in expected returns and allows to use many factors and asset classes in asset allocation.

Martha Liliana Carren \& et al (2007) this article proposed the risk management index which defined as average of risk identification index, risk reduction index, disaster management index and the degree of institutionalization and risk transfer to evaluate management performance, this index provides a quantitative measure of management.

Ronald Klingebiel \& Christian Rammer (2013)this article used correlation to analyze relationship between resource allocation and innovation portfolio management, it found a positive relationship between innovation performance on allocation resource, alsothere is significant statically relationship between resource allocation breadth on performance but insignificant relationship between overall firm sales new product on performance and positive significant relationship between sales new to firm and new sales to market on performance. 
Magnus Dahlquist \& et al (2018)this article used a life- cycle consumption saving model to investigate the impact of different equity in the default fund, the result shows that the optimal asset allocation rule depend on heavily investors pension fund account balance and stock market

Giorgio Consigli \& et al (2018)the objective of this paper is asset -liability management model formulation based on relationship between rerun and risk the evidence of this study that an optimal tradeoff between profitability and risk capital allocation also the model conducted to an optimal tradeoff between increasing capital requirements and paid capital.

Jan Dhaene \& et al (2012)this paper developed optimization model based on minimization the sum of difference between risk and allocated capital, this model developed in this paper shown that the flexibility to present new an optimal capital allocation framework.

Michael T. Todinov (2014) a proposed model in this study is the (0-1) knapsack dynamic programming model for optimal allocation the results show that the (0-1) knapsack dynamic programming model maximizes total expected benefit and the suggested model presented solution to (cost -benefit analysis / knapsack dynamic programming) that has been further consolidated an efficient uses of risk reduction by preventing insignificant benefit improvement.

Gerald R. Jensen \& Jeffrey M. Mercer (2003) the analysis relative improvement in return ratio over buy - hold strategy showed that portfolio lies inside the efficient frontier, furthermore the findings indicate that the monetary cycle has a greater effect than business cycle on return, also there is a significant relationship between an in -sample allocation strategy depend on monetary cycle on risk -adjusted return after transaction cost.

Roy P. P. M. Hoevenaars \& et al (2013) they investigated the effect of uncertainty on long term risk and asset allocation the findings indicate that parameter uncertainty impact on stocks bonds and treasury bills, also parameter changes optimal portfolio allocation furthermore the effect of investment horizon on optimal portfolio.

Libo Yin \& Liyan Han (2013) the main objective of this paper to examine the feasibility of Multistage Stochastic Programming Model for the optimization international portfolio computational efficiency and relative superiority of optimal hedge approach, the MSSP model reveals that effectiveness with respect to return distribution, the MSSP model overbear in terms of profitability more than classic approaches also provides an inverse relationship between risk aversion and return.

Thanh T. Nguyen \& et al (2015) this study introduced a new risk measure uncertainty of portfolio returns and concluded portfolio performance ratio also presented a genetic algorithm method to solve portfolio problems that in series of well diversified portfolio.

Jing Ai \& et al (2011)this article presented a mathematically formulated dynamic model thatuses value at risk, variance, semi variance and expected shortfall to determine the optimal allocation portfolio beside that this model allows a choice of desirable risk levels and risk appetite.

J. David Cummins (2000) proposed the regulatory risk based capital model for capital allocation and critiques to the optimal allocation techniques the results show risk at value provides less information than expected policy holder's deficit, the proposed approach exceeds the firms overall capital,the option model gives result better than risk at value and expected policyholders deficit regarding to capital allocation, the cost of capital allocated is high more than capital invested in capital market and the allocation of resources must include assets risk and liability risk.

Mary A. Weiss (2010) the main objective of this study is to examine whether insurance industry in US is systemically risk which divide systemic risk to leverage, liquidity size, regulation government policy and other factors the results refer to that insurance are not predicated instigators or cause of systemic risk and there is relationship between systemic risk on leverage, liquidity, regulation government policy and others factors, add to that this study exposed that insurance pre funded by payment of premium.

J. David Cummins \& David W. Sommer (1996) they proposed a model to analyze relationship between capitalization and risk levels based on option theory using a simulation equation methodology in insurance sector in US the finding refer to that there is a positive significant relationship between portfolio risk measured by standard deviation and capital measured by capital to asset ratio, the model exposed evidence that managerial incentives effect on determining capital and risk in insurance market.

Veronique M.-Deschamps \& et al (2015) they presented a multivariate of risk as a capital allocation approach is considered coherent from an economic viewpoint and it's effected on management of overall firm's capital and reduce its overall risk. 
Jacob van der B \& Tinashe Tholana (2020) this paper investigated the factors which effected on capital allocation decision making in mining companies, the study found that growth volume has a strong relationship with the value of capital approvals, also they should disposal of asset that not meet the investment criteria and reduction net debt.

\section{Development of Hypotheses and Methodology}

By reviewing the previous studies as applied in financial intermediates sector especially in banks and insurance, it was most of them related to proposed models for capital allocation approaches which have been studied extensively. As for J. David Cummins (2000), Veronique M.-Deschamps \& et al (2015) Michael T. Todinov (2014), Jan Dhaene \& et al (2012), Giorgio Consigli \& et al (2018), J. David Cummins \& David W. Sommer (1996) and Michael Sherris (2006), while This paper would be remiss to analyze the relationship between sources allocation as independent variables and risk performance as dependent variables is divided into financial risk measured by standard deviation of return on equity and business risk measured by standard deviation of return on assets by using statistical techniques ARDL and GARCH model.

There is no statistically difference between capital ratio and risk performance.

There is no statistically difference between asset allocation and risk performance.

\subsection{Risk Performance Measure as Dependent Variables}

Standard deviation of Return on Equity

$$
\text { ST of ROE }=\sqrt{\frac{(R O E-(R O E)-)^{2}}{N-1}}
$$

Standard deviation of Return on Assets

$$
\text { ST of ROA }=\sqrt{\frac{\left(R O A-(\text { ROA })^{-}\right)^{2}}{N-1}}
$$

This study in concur with Nejat Capar \& et al (2015) regarding to risk performance as dependent variable but the difference in measured by volatility of return on asset only.

This is consistent with Meng-Fen Hsieh \& et al 2015 their dependent variables have been selected to reflect the diversity return on asset, return on equity standard deviation of return on equity, standard deviation of return on asset, leverage and Tobin otherwise this study selected the standard deviationof return on equity and standard deviation of return on assets to reflect the risk performance

\subsection{Resource Allocation Measures as Independent Variables}

Capital Structure $=($ Total Liabilities - Equity $) /$ Total Assets

Assets structure $=($ free investment assets + allocated investment assets $) /$ total assets

\section{Empirical Analysis}

\subsection{Jarque-Bera Test}

To measure the normality distribution of all research variables: the following table indicates that the descriptive statistics of data used, mean, median, maximum mime. Standard deviation, skewness kurtosis and Jarque Bera of dependent variables (standard deviation of return on equity, standard deviation of return on assets), and independent variables (capital structure and asset structure) the data are yearly from 1999 -2019. That shows non normal distribution when Jarque Bera probability less than (0.05) also, Since the Pearson skewness coefficient is less than or equal (1) or greater than or equal $(-1),(-1 \leq P S C \leq 1)$ it can be concluded that the data are not significantly skewed.

Table 1. Descriptive analysis for dependent and independent variables

\begin{tabular}{ccccc}
\hline Constructs & Y1 & Y2 & X1 & X2 \\
\hline Mean & 0.014998 & 0.054270 & 0.815694 & 0.745912 \\
Median & 0.012432 & 0.047220 & 0.824534 & 0.766671 \\
Maximum & 0.042087 & 0.147832 & 0.993822 & 0.983015
\end{tabular}




$\begin{array}{ccccc}\text { Minimum } & 4.67 \mathrm{E}-05 & 0.000747 & 0.569506 & 0.457894 \\ \text { Std. Dev. } & 0.010919 & 0.036553 & 0.095153 & 0.121204 \\ \text { Skewness } & 0.733731 & 0.545950 & -0.301571 & -0.416374 \\ \text { Kurtosis } & 2.650187 & 2.386605 & 2.598400 & 2.623403 \\ \text { Jarque-Bera } & 37.83545 & 26.07632 & 8.729166 & 13.88677 \\ \text { Probability } & 0.001 * * * & 0.001 * * * & 0.012720^{*} & 0.000965^{* * *}\end{array}$

*** Probability at a level less than (0.001).

\subsection{Group Unit Root Test}

By using statistical techniques like, Philips-Perrron (PP), and Im, Pesaran and Shin W-stat (IPSW).and Augmented Dickey-Fuller (ADF The study able to measure the stationary of time series to make sure that the mean and variance are invariant over time, and the value of the covariance between two time periods depends only on the distance between the two time periods and not the actual time at which the covariance is computed of standard deviation of return on equity, standard deviation of return on assets, capital structure and asset structure.

Table 2. The values of (G U R T) Group unit root test for risk performance and sources allocation

\begin{tabular}{lcccc}
\hline Method & Statistic & Prob.** & $\begin{array}{c}\text { Cross- } \\
\text { sections }\end{array}$ & Obs \\
\hline $\begin{array}{l}\text { Null: Unit root (assumes common unit root process) } \\
\text { Levin, Lin \& Chu t* }\end{array}$ & -7.41235 & $0.001^{* * *}$ & 4 & 1590 \\
& & & \\
Null: Unit root (assumes individual unit root process) \\
Im, Pesaran and Shin \\
W-stat & -10.3641 & $0.001^{* * *}$ & 4 & 1590 \\
ADF - Fisher Chi-square & 122.593 & $0.001^{* * *}$ & 4 & 1590 \\
PP - Fisher Chi-square & 159.931 & $0.001^{* * *}$ & 4 & 1592 \\
\hline
\end{tabular}

As for the second table reports that stationary of the time series of the standard deviation of return on equity $\mathrm{y} 1$, standard deviation of return on assets $\mathrm{y} 2$, capital structure $\mathrm{x} 1$, and asset structure $\mathrm{x} 2$, at level $1 \sim(0)$ based on the constant level, through to the following criteria;LLC, IPSW, PP, ADF, at a probability level less than (0.001).

\subsection{Co-integrating Equation Model}

Engle-Granger Co-integration test, $\mathrm{t}$

To measure the existence of long-run equilibrium relationship between of standard deviation of return on equity $\mathrm{y} 1$ and standard deviation of return on assets $\mathrm{y} 2$ on capital structure $\mathrm{x} 1$, and asset structure $\mathrm{x} 2$ and no stationary time series variables, as follows: 
Table 3. Analyzing the model of cointegrating for standard deviation of return on equity and standard deviation of return on assets as dependent variables on capital structure and assets structure as independent variables from 1999 to 2019

\begin{tabular}{ccccc}
\hline Dependent & tau-statistic & Prob.* & z-statistic & Prob.* \\
\hline Y1 & -8.790026 & $0.001 * * *$ & -129.6741 & $0.001^{* * *}$ \\
Y2 & -8.872353 & $0.001^{* * *}$ & -131.6727 & $0.001^{* * *}$ \\
X1 & -6.929211 & $0.001 * * *$ & -85.75562 & $0.001 * * *$ \\
X2 & -7.194718 & $0.001 * * *$ & -91.58538 & $0.001 * * *$ \\
\hline
\end{tabular}

As for the third Table reports that there is long-term equilibrium relationships between dependent and independent variables from 1999 to 2019, and based on the both Tau-statistic, and z-statistic, at a probability level less than (0.001).

\subsection{The Values of Pearson Correlation in the Following Matrix}

Table 4. Pearson correlation matrix to measure a significant linear relationship between the variables of the ARDL and GARCH model

\begin{tabular}{|c|c|c|c|c|}
\hline Constructs & Y1 & Y2 & X1 & $\mathbf{X} 2$ \\
\hline Y1 & 1 & & & \\
\hline Y2 & $0.848 * * *$ & 1 & & \\
\hline $\mathrm{X} 1$ & $-0.130 * *$ & -0.0156 & 1 & \\
\hline $\mathrm{X} 2$ & $-0.124 *$ & $0.289 * * *$ & $0.273 * * *$ & 1 \\
\hline
\end{tabular}

*** Probability at a level less than (0.001).** Interval forecast alevelgreet than $(0.99)$. Interval forecast a level great than $(0.95)$.

The Table 4 shows that:

- There is a significant negative linear relationship between the independent variable capital structure $\mathrm{x} 1$ and asset structure $\mathrm{x} 2$ and dependent variable standard deviation of return on equity y1 at a significant level less than (0.05).

- $\quad$ There is a significant positive linear relationships between the independent variable asset structure $\mathrm{x}_{2}$ and dependent variable; standard deviation of return on assets $\mathrm{y}_{2}$ at a probability level less than $(0.001)$.

\subsection{ARDL and GARCH Model}

By using the binding testing method to co-integration and error correction models which developed within (ARDL) an autoregressive distributed lag model, to examine whether a long-run equilibrium relationship exists between variables through the work of Pesaran correlation

In this paper GARCH model developed for many reasons first (forecast volatility, analyze the risk of holding an asset). Second, forecast confidence intervals may be time-varying, so that more accurate intervals can be obtained by modeling the variance of the errors. Third, more efficient estimators can be obtained if heteroskedasticity in the errors is handled properly.

The reason for using Autoregressive Conditional Heteroskedasticity (ARCH) models to forecast conditional variances. The variance of the dependent variable is modeled as a function of past values of the dependent variable and independent or exogenous variables. 
3.5.1 The effect of capital structure $\mathrm{x} 1$, and asset structure $\mathrm{x} 2$ on standard deviation of return on equity $\mathrm{y} 1$ by using the ARDL and GARCH model

$$
\operatorname{STRE}(Y 1)=\alpha+\sum_{i=1}^{p} \gamma_{i} y_{t-1}+\sum_{j=1}^{k} \sum_{i=0}^{q_{j}} X_{j, t-i^{\prime}} \beta_{j, i}+\varepsilon_{t}
$$

Where ST ROE Standard Deviation of Return On Equity

Table 5. ARDL $(2,0,2)$ model to determine the fit co-integration and error correction models of independent variables on standard deviation of return on equity $\mathrm{Y} 1$

\begin{tabular}{|c|c|c|c|c|c|}
\hline Variable & Coefficient & Std. Error & t-Statistic & Prob. & VIF \\
\hline Y1(-1) & 0.578587 & 0.049706 & 11.64024 & $0.001 * * *$ & 2.056093 \\
\hline $\mathrm{Y} 1(-2)$ & 0.181599 & 0.049549 & 3.665030 & $0.001 * * *$ & 2.043073 \\
\hline X1 & 0.001262 & 0.004237 & 0.297934 & 0.7659 & 1.131769 \\
\hline $\mathrm{X} 2$ & -0.000706 & 0.006349 & -0.111148 & 0.9116 & 4.117825 \\
\hline $\mathrm{X} 2(-1)$ & 0.008574 & 0.007974 & 1.075321 & 0.2829 & 6.506598 \\
\hline $\mathrm{X} 2(-2)$ & -0.012785 & 0.006390 & -2.000678 & $0.0461^{*}$ & 4.186302 \\
\hline $\mathrm{C}$ & 0.006240 & 0.003838 & 1.625740 & 0.1048 & --- \\
\hline \multicolumn{6}{|c|}{$\begin{array}{c}\mathrm{DW}=1.97 \mathrm{JB}=156.7 \mathrm{sig}=0.001 \mathrm{ARDL} \text { Bounds Test } \mathrm{F} \text { test }=13.7 \mathrm{CVB} 1 \%=(5.15,6.36) \quad \text { Heteroskedasticity Test: } \\
\text { ARCH F test }=0.233 \mathrm{sig}=0.63\end{array}$} \\
\hline \multicolumn{6}{|c|}{$\begin{array}{c}\mathrm{Y} 1=0.578587434584 * Y 1(-1)+0.181598693876 * Y 1(-2)+0.0012622744933 * X 1-0.0007056717256 * X 2+ \\
0.0085742849271 * X 2(-1)-0.0127851590277 * X 2(-2)+0.00624006298853\end{array}$} \\
\hline \multicolumn{6}{|c|}{$\begin{array}{c}\text { Co-integrating Equation: } \mathrm{D}(\mathrm{Y} 1)=-0.181598693876 * \mathrm{D}(\mathrm{Y} 1(-1))+0.001262274493 * \mathrm{D}(\mathrm{X} 1) \\
-0.000705671726 * \mathrm{D}(\mathrm{X} 2)+0.012785159028 * \mathrm{D}(\mathrm{X} 2(-1))-0.239813871539 *(\mathrm{Y} 1-(0.00526356 * \mathrm{X} 1(-1) \\
-0.02050151 * \mathrm{X} 2(-1)+0.02602044))\end{array}$} \\
\hline
\end{tabular}

Table 6. GARCH $(1,1)$ model Normal distribution to determine the effect of independent variables $\mathrm{x} 1$ and $\mathrm{x} 2 \mathrm{onY} 1$

\begin{tabular}{|c|c|c|c|c|c|}
\hline Variable & Coefficient & Std. Error & Z-Statistic & Prob. & VIF \\
\hline $\mathrm{Y} 1(-1)$ & 0.530825 & 0.069872 & 7.597165 & $0.001 * * *$ & 2.056093 \\
\hline $\mathrm{Y} 1(-2)$ & 0.170606 & 0.066496 & 2.565637 & $0.0103 *$ & 2.043073 \\
\hline $\mathrm{X} 1$ & -0.006079 & 0.002664 & -2.281468 & $0.0225^{*}$ & 1.131769 \\
\hline $\mathrm{X} 2$ & $2.46 \mathrm{E}-05$ & 0.005469 & 0.004505 & 0.9964 & 4.117825 \\
\hline $\mathrm{X} 2(-1)$ & 0.013143 & 0.006892 & 1.907096 & $0.0565 *$ & 6.506598 \\
\hline $\mathrm{X} 2(-2)$ & -0.015664 & 0.004879 & -3.210264 & $0.0013 * *$ & 4.186302 \\
\hline $\mathrm{C}$ & 0.010737 & 0.002966 & 3.619872 & $0.001 * * *$ & --- \\
\hline \multicolumn{6}{|c|}{ Variance equation } \\
\hline $\mathrm{C}$ & $1.56 \mathrm{E}-05$ & $2.55 \mathrm{E}-06$ & 6.120988 & $0.001 * * *$ & --- \\
\hline $\operatorname{RESID}(-1)^{\wedge} 2$ & 0.380285 & 0.106920 & 3.556709 & $0.001 * * *$ & --- \\
\hline GARCH(-1) & 0.402776 & 0.063902 & 6.302977 & $0.001 * * *$ & --- \\
\hline $\mathrm{R}^{2}=52.2 \% \quad \begin{array}{r}\mathrm{AIC} \\
\mathrm{sig}=\end{array}$ & \multicolumn{5}{|c|}{$\begin{array}{l}\mathrm{AIC}=-7.02 \quad \mathrm{SC}=-6.90 \mathrm{HQC}=-6.96 \mathrm{RMSE}=0.008 \mathrm{U}=0.217 \quad \mathrm{DW}=1.86 \mathrm{JB}=166.1 \\
\text { sig }=0.001 \text { Heteroskedasticity Test: } \mathrm{ARCH} \quad \text { F test }=0.067 \mathrm{sig}=0.796\end{array}$} \\
\hline \multicolumn{6}{|c|}{$\begin{array}{c}\mathrm{Y} 1=0.530825326262 * \mathrm{Y} 1(-1)+0.170605581344 * \mathrm{Y} 1(-2)-0.0060785670247 * \mathrm{X} 1+2.46376768278 \mathrm{e}-05 * \mathrm{X} 2+ \\
0.0131431969206 * \mathrm{X} 2(-1)-0.0156644811334 * \mathrm{X} 2(-2)+0.0107372662237\end{array}$} \\
\hline \multicolumn{6}{|c|}{$\mathrm{GARCH}=1.5622687231 \mathrm{e}-05+0.380284778701 * \operatorname{RESID}(-1)^{\wedge} 2+0.402775548885^{*} \operatorname{GARCH}(-1)$} \\
\hline
\end{tabular}


According to the method of ML ARCH - (BFGS / Marquardt steps), Maximum dependent lags: 4 (Automatic selection), Model selection method: Akaike info criterion (AIC), Number of models evaluated: 100, the Selected Model: ARDL (2, $0,2)$, and the GARCH $(1,1)$ model - Normal distribution it can be concluded that:

\section{1- The value of $R^{2}$ (coefficient of determination)}

Based on the result show in above table that capital structure and asset structure as the Independent Variables were accepted in the ARDL $(2,0,2)$, and the GARCH $(1,1)$ model explain $(52-53 \%)$ from total variation of dependent variable standard deviation of return on equity (y1).

\section{2- The value of $F$ test}

Since the value of "F test" in the $\operatorname{ARDL}(2,0,2)$ is $(73.7)$ at a significant level atless than $(0.001)$, then the researcher concludes that the independent variables were accepted in the model have been affected on the level of $\mathrm{y} 1$.

\section{3- The value of the T-test $\&$ Z-test}

The most significant independent variables were accepted in the $\operatorname{ARDL}(2,0,2)$, and the $\operatorname{GARCH}(1,1)$ model are: $\mathrm{Y} 1(-1)$, Y1 (-2), X1, X2(-1), and X2(-2) at a significant level less than (0.05). Furthermore, There is a significant positive effect of the ARCH term, measured as the lag of the squared residual from the mean equation, and the GARCH term, Last period's forecast variance, at a significant level less than (0.001).it means that the high volatility in the conditional variance of standard deviation of return on equity yl.also The sum of the two parameters of: $(\alpha+\beta)$ in the GARCH model $(1,1)$ whether the random error are distributed according to normal distribution methods is the positive one, which indicates that the two conditional of non-negative variance, and the variance is not inflated are satisfied, and that Indication of the continuity of volatility shocks in the standard deviation of return on equity y1.

\section{4- Variance Inflation Factors(VIF)}

As for on the above table, the value of VIP less than 4, therefore the ARDL $(2,0,2)$, and the GARCH $(1,1)$ model have not suffering from the multicollinearity problem.

\section{5- The Jarque-Bera Test}

Since the significance value of the test statistic for both models $(<0.05)$, then we would reject the null hypothesis $\left(\mathrm{H}_{0}\right)$ : residuals are normally distributed. But Pearson skewness coefficient is less than (1), it can be concluded that the data are not significantly skewed.

\section{6- Theil's inequality coefficient $U$}

This test is used to measure the accuracy of the estimates of the $\operatorname{ARDL}(2,0,2)$ and the $\operatorname{GARCH}(1,1)$ model. It lies between zero and one, where zero indicates a perfect fit. Since a coefficient $U$ reaches to (0.21-0.22) indicating the goodness of fit of the both models, at a percent of not less than (78\%).

\section{7- Akaike information criteria for top 20 models}

Based on the value of the AIC index, the best fit model for explaining the behavior of the dependent variable ylare the ARDL $(2,0,2)$, and GARCH $(1,1)$ model, where that $\mathrm{AIC}=(-7.02,-6.91), \mathrm{SC}=(-6.90,-6.85), \mathrm{HQC}=(-6.96,-6.88)$, and Adj. R-sq=(52-53\%)

\section{8- ARDL Bounds Test}

Since calculated value of the ARDL Bounds F-statistic (13.67) test is greater than the tabulated value at a significant level (1\%), (5.15-6.36) indicating the rejection of the null hypothesis that there is no long-term relationships between the variables of the ARDL $(2,0,2)$ model and then accepting the alternative hypothesis that there are long-term relationships between the independent variables and standard deviation of return on equity y1. Since the t-statistic of "CointEq (-1)" is (-6.28) at a significant level at less than (0.001), then the conclude shows that capital structure and asset structure as independent variables granger - causes standard deviation of return on equity (y1) in the long run.

\section{9- The Durbin-Watson test statistic}

Table reports the test statistic value (1.86-1.97) was greater than Du (1.746), so the null hypothesis is accepted, that the residuals from an Ordinary least-squares regression are not auto correlated against the alternative that the Residuals follow an AR1, positive first-order autocorrelation, process. 


\section{0- Heteroskedasticity Test}

By conducting the Heteroskedasticity Test: ARCH for the residuals values of the ARDL $(2,0,2)$, and GARCH $(1,1)$ model, it revealed that the level of significance for the tests: F-statistic, Obs * R-squared, is greater than (0.05); which indicates the acceptance of the null hypothesis which provides for the Homoskedasticity of error term.

3.5.2 The effect of capital structure $\mathrm{x} 1$ and asset structure $\mathrm{x} 2$ on standard deviation of return on equity $\mathrm{y} 2$ by using the ARDL and GARCH model

$$
S T R O A(Y 2)=\alpha+\sum_{i=1}^{p} \gamma_{i} y_{t-1}+\sum_{j=1}^{k} \sum_{i=0}^{q_{j}} X_{j, t-i^{\prime}} \beta_{j, i}+\varepsilon_{t}
$$

Where ST ROA Standard Deviation of Return On Assets

Table 7. ARDL $(3,0,0)$ model to determine the fit co-integration and error correction models of independent variables on standard deviation of return on asset Y2

\begin{tabular}{|c|c|c|c|c|c|}
\hline Variable & Coefficient & Std. Error & t-Statistic & Prob. & VIF \\
\hline $\mathrm{Y} 2(-1)$ & 0.600935 & 0.049949 & 12.03096 & $0.001 * * *$ & 2.225420 \\
\hline $\mathrm{Y} 2(-2)$ & 0.194745 & 0.057452 & 3.389670 & $0.001 * * *$ & 2.943152 \\
\hline $\mathrm{Y} 2(-3)$ & -0.073589 & 0.049496 & -1.486755 & 0.1379 & 2.184042 \\
\hline $\mathrm{X} 1$ & -0.013373 & 0.013446 & -0.994525 & 0.3206 & 1.089516 \\
\hline $\mathrm{X} 2$ & 0.033023 & 0.010976 & 3.008713 & $0.0028 * *$ & 1.174749 \\
\hline $\mathrm{C}$ & 0.001198 & 0.011690 & 0.102481 & 0.9184 & -- \\
\hline \multicolumn{6}{|c|}{$\begin{array}{c}\mathrm{R}^{2}=55.8 \% \quad \mathrm{~F} \text {-test }=98.66 \mathrm{sig}=0.001 * * * \quad \mathrm{AIC}=-4.57 \quad \mathrm{SC}=-4.51 \mathrm{HQC}=-4.55 \mathrm{RMSE}=0.024 \mathrm{U}=0.193 \\
=1.98 \mathrm{JB}=88.1 \mathrm{sig}=0.001 \mathrm{ARDL} \text { Bounds Test } \mathrm{F} \text { test }=15.3 \mathrm{CVB} 1 \%=(5.15,6.36) \quad \text { Heteroskedasticity Test: } \mathrm{ARCH}\end{array}$} \\
\hline \multicolumn{6}{|c|}{$\begin{array}{c}\mathrm{Y} 2=0.600934788174 * \mathrm{Y} 2(-1)+0.194744757488 * \mathrm{Y} 2(-2)-0.0735891462886 * \mathrm{Y} 2(-3)-0.0133728366313 * \mathrm{X} 1+ \\
0.0330229417613 * \mathrm{X} 2+0.0011980128244\end{array}$} \\
\hline \multicolumn{6}{|c|}{ 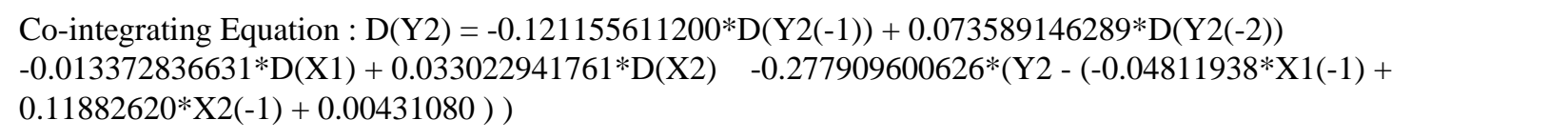 } \\
\hline \multicolumn{6}{|c|}{ Table 8. GARCH $(1,1)$ model normal distribution to determinethe effect of independent variables $\mathrm{x} 1$ and $\mathrm{x} 2 \mathrm{onY} 2$} \\
\hline Variable & Coefficient & Std. Error & Z-Statistic & Prob. & VIF \\
\hline $\mathrm{Y} 2(-1)$ & 0.612111 & 0.032660 & 18.74168 & $0.001 * * *$ & 2.225420 \\
\hline $\mathrm{Y} 2(-2)$ & 0.207013 & 0.039669 & 5.218529 & $0.001 * * *$ & 2.943152 \\
\hline $\mathrm{Y} 2(-3)$ & -0.095902 & 0.040000 & -2.397549 & $0.0165^{*}$ & 2.184042 \\
\hline $\mathrm{X} 1$ & -0.011882 & 0.011075 & -1.072888 & 0.2833 & 1.089516 \\
\hline $\mathrm{X} 2$ & 0.033118 & 0.010739 & 3.083850 & $0.0020 * *$ & 1.174749 \\
\hline $\mathrm{C}$ & $-3.88 \mathrm{E}-05$ & 0.010175 & -0.003809 & 0.9970 & -- \\
\hline \multicolumn{6}{|c|}{ Variance equation } \\
\hline $\operatorname{RESID}(-1)^{\wedge} 2$ & 0.007283 & 0.003583 & 2.032834 & $0.0421 *$ & --- \\
\hline GARCH(-1) & 0.992717 & 0.003583 & 277.0883 & $0.001 * * *$ & --- \\
\hline \multicolumn{6}{|c|}{$\begin{array}{c}\mathrm{AIC}=-4.55 \quad \mathrm{SC}=-4.48 \mathrm{HQC}=-4.53 \mathrm{RMSE}=0.024 \mathrm{U}=0.192 \quad \mathrm{DW}=1.999 \mathrm{JB}=96.4 \\
\mathrm{sig}=0.001 \text { Heteroskedasticity Test: } \mathrm{ARCH} \quad \mathrm{F} \text { test }=1.62 \mathrm{sig}=0.077\end{array}$} \\
\hline \multicolumn{6}{|c|}{$\begin{array}{c}\mathrm{Y} 2=0.612110679659 * \mathrm{Y} 2(-1)+0.207013329668 * \mathrm{Y} 2(-2)-0.0959021815336 * \mathrm{Y} 2(-3)-0.0118824431443 * \mathrm{X} 1+ \\
0.0331182002982 * \mathrm{X} 2-3.87593955871 \mathrm{e}-05\end{array}$} \\
\hline \multicolumn{6}{|c|}{$\mathrm{GARCH}=0.0072829821719 * \mathrm{RESID}(-1)^{\wedge} 2+(1-0.0072829821719) * \mathrm{GARCH}(-1)$} \\
\hline
\end{tabular}


According to the method of ARDL, Maximum dependent lags: 4 (Automatic selection), Model selection method: Akaike info criterion (AIC), Number of models evaluated: 100, the Selected Model: ARDL (3, 0, 0), and the GARCH $(1,1)$ model - Normal distribution it can be concluded that:

\section{1- The coefficient of determination: $\mathbf{R}^{2}$}

Based on the result in above table the Independent Variables were accepted in the ARDL (3, 0, 0), and the GARCH $(1,1)$ model explain $(55.8 \%)$ from total variation of dependent variable standard deviation of return on asset $(y 2)$.

\section{2- $\quad$ F test}

Where the value of "F test" in the ARDL $(3,0,0)$ is $(98.7)$ at a significant level at less than $(0.001)$, the result shows that the independent variables were accepted in the model have been affected on the level of standard deviation on return on assets y2.

\section{3- The value of T-test \& Z-test}

The significant independent variables (capital structure and asset structure) were accepted in the ARDL (2, 0, 2), and the GARCH $(1,1)$ model are: Y2 $(-1)$, Y2 (-2), Y2 (-3), and asset structure $(X 2)$, at a probability $\geq(0.05)$. Moreover, There is a significant positive effect of the ARCH term, measured as the lag of the squared residual from the mean equation, and the GARCH term, Last period's forecast variance, at a significant level less than (0.05).it means that the high volatility in the conditional variance of standard deviation of return on assets (Y2). Also the sum of the two parameters of: $(\alpha+\beta)$ in the GARCH model $(1,1)$ whether the random error are distributed based on normal distribution methods is a positive one, which indicates that the two conditions of non-negative variance, and the variance is not inflated are satisfied, and that Indication of the continuity of volatility shocks in the standard deviation of return on assets (Y2).

\section{4- VIF: Variance Inflation Factors}

As for The above table, it reports the value of VIP less than 4 , therefore the ARDL $(3,0,0)$, and the GARCH (1, 1$)$ model have not suffering from the multicollinearity problem.

\section{5- The Jarque-Bera Test}

Since the significance value of the test statistic for both models $(<0.05)$, based on this finding indicates that the null hypothesis $\left(\mathrm{H}_{0}\right)$ is rejected, also Pearson skewness coefficient is less than (1), it can be concluded that the data are not significantly skewed.

\section{6- The test of Theil's inequality coefficient $U$}

This test is used to measure the accuracy of the estimates of the ARDL $(3,0,0)$ and the GARCH $(1,1)$ model. It ranges $(0-1)$, where zero indicates a perfect fit. Since a coefficient $U$ reaches to $(0.19)$ indicating the goodness of fit of the both models, at a percent of less than $(81 \%)$.

\section{7- Akaike information criteria for top 20 models}

Based on the value of the AIC index, the best fit model for explaining the behavior of the dependent variable $\mathrm{y} 1$ are the ARDL $(3,0,0)$, and GARCH $(1,1)$ model, where that $\mathrm{AIC}=(-4.57,-4.55), \mathrm{SC}=(-4.51,-4.48)$, $\mathrm{HQC}=(-4.55,-4.53)$, and Adj. R-sq $=(56 \%)$

\section{8- ARDL Bounds Test}

Since the calculated value of the ARDL Bounds F-statistic (15.3) test is greater than the tabulated value at a significant level (1\%), (5.15-6.36) indicating the rejection of the null hypothesis that there are no long-term relationships between the variables of the $\operatorname{ARDL}(3,0,0)$ model and then accepting the alternative hypothesis that there are long-term relationships between the independent variables and y1. Since the t-statistic of "CointEq (-1)" is (-7.06) at a significant level at less than (0.001), then the researcher concludes that the independent variables granger - causes y2in the long run

\section{9- The value of The Durbin-Watson test statistic}

Where the test statistic value (1.98-1.99) was greater than $\mathrm{Du}(1.746)$, based on the result the null hypothesis is rejected. That the residuals from an Ordinary least-squares regression are not auto correlated against the alternative that the Residuals follow an AR1, positive first-order autocorrelation, process.

\section{0- Heteroskedasticity Test}

By conducting the Heteroskedasticity Test: ARCH for the residuals values of the ARDL $(3,0,0)$, and GARCH (1, 1) model, it revealed that the level of significance for the tests: F-statistic, Obs * R-squared, is greater than (0.05); which indicates the acceptance of the null hypothesis which provides for the Homoskedasticity of error term. 


\section{Conclusions}

The mean objective of current paper was to investigate the relationship between sources allocations measured by (external sources to total assets- free investment and allocated investment to total assets) on risk performance measured by financial risk (standard deviation of return on equity) business risk (standard deviation of return on assets) using ARDL and GARCH model, using a sample of 19 Egyptian insurance companies over a 21 year period form $1999-2019$,

1-There is a significant negativelinear relationships between the independent variable capital structure $\mathrm{x} 1$ and asset structure $\mathrm{x} 2$ and dependent variable standard deviation of return on equity y1 at a significant level less than (0.05).

2-There is a significant positive linear relationships between the independent variable asset structure $\mathrm{x} 2$ and dependent variable; standard deviation of return on assets y2 at a Significant level less than (0.001).

With regard to ARCH and GARCH the findings indicate to

3-There is a significant positive effect of the ARCH term, measured as the lag of the squared residual from the mean equation, and the GARCH term, Last period's forecast variance, at a significant level less than (0.001). It means that the high volatility in the conditional variance of standard deviation of return on equity y1. also The sum of the two parameters of: $(\alpha+\beta)$ in the GARCH model $(1,1)$ whether the random error are distributed according to normal distribution methods is the positive one, which indicates that the two conditional of non-negative variance, and the variance is not inflated are satisfied, and that Indication of the continuity of volatility shocks in the standard deviation of return on equity.

4- There is a significant positive effect of the ARCH term, measured as the lag of the squared residual from the mean equation, and the GARCH term, Last period's forecast variance, at a significant level less than (0.05). It means that the high volatility in the conditional variance of standard deviation of return on assets y2. Also the sum of the two parameters of: $(\alpha+\beta)$ in the GARCH model $(1,1)$ whether the random error are distributed according to normal distribution approaches the positive one, which indicates that the two conditions of non-negative variance, and the variance is not inflated are satisfied, and that Indication of the continuity of volatility shocks in the standard deviation of return on assets y2.

\section{References}

Ai, J., \& et al.. (2011). Enterprise Risk Management through Strategic Allocation of Capital. Journal of Risk and Insurance, 79(1).

Amey, L. R. (1964). The Allocation and Utilization of Resources. Operational Research Quarterly, 15(2).

Basak, S., \& Makarov, D. (2008). Strategic Asset Allocation with Relative Performance Concerns. https://doi.org/10.2139/ssrn.1011768

Bielecki, T. R., \& et al.. (2000). Risk sensitive asset allocation. Journal of Economic Dynamics \& Control, 24(8). https://doi.org/10.1016/S0165-1889 (99)00017-2

Blake, D., \& et al.. (1999). Asset Allocation Dynamics and Pension Fund Performance. The Journal of Business, 72(4). https://doi.org/10.1086/209623

Bock, J. M. (2013). Evidence from German companies of Effects of Corporate Risk Management on Capital Structure Decisions. Journal of Applied Corporate Finance, 25(4).

Capar, N., \& et al.. (2015). Effects of International Diversification and Firm Resources on Firm Performance Risk. Journal of Management and Strategy, 6(1). https://doi.org/10.5430/jms.v6n1p10

Carren, M. L., \& et al.. (2007). A disaster risk management performance index. Journal of Natural Hazard, 4l(1). https://doi.org/10.1007/s11069-006-9008-y.

Casarin, R., \& Billio, M. (2007). StochasticOptimization for Allocation Problems with shortfall Risk Constraints. Journal of Applied Stochastic Models in Business and Industry, 23(3). https://doi.org/10.1002/asmb.671

Consigli, G., \& et al.. (2018). Optimal insurance portfolios risk-adjusted performance through dynamic stochastic programming. https://doi.org/10.1007/s10287-018-0328-7

Cummins, J. D. (2000). Allocation ofCapital in the Insurance industry. Risk Management and Insurance Review, 3(1), 7-27.

Cummins, J. D., \& Sommer, D. W. (1996). Capital and risk in property-liability insurance markets. Journal of Banking \& Finance, 20. 
Dahlquist, M., \& et al.. (2018). On the Asset Allocation of a Default Pension Fund. The Journal of Finance, $\operatorname{LXXIII(4).~}$

Delsing, G. A., \& et al.. (2012). On Capital Allocation for a Risk Measure Derived from Ruin Theory.

Dhaene, J., \& et al.. (2012). Optimal Capital Allocation Principles. The Journal of Risk and Insurance.

Hoevenaars, R. P. P. M., \& et al.. (2013). Strategic Asset Allocation for long -TermInvestor: Parameter Uncertainty and Prior Information. Journal of Applied Econometrics, 29. https://doi.org/10.1002/jae.2331

Hsieh, M-F., \& et al.. (2015). The Impact of Diversification on Performance in the Insurance Industry: The Roles of Globalization. Financial Reforms and Global Crisis. https://doi.org/10.1057/gpp.2015.6

Jacob, van der B., \& Tholana, T. (2020). Analysis of Capital Allocation by Mining Companies. https://doi.org/10.1007/978-3-030-33954-8_39

Jensen, G. R., \& Mercer, J. M. (2003). New Evidence on Optimal Asset Allocation. The Financial Review, 38.

Kahloul, I., \& Hallara, S. (2010). The Impact of Diversification on Firm Performance and Risk: An Empirical Evidence. International Research Journal of Finance and Economics, (35).

Kalkbrener, M. (2005). An Axiomatic Approach to capital Allocation. Mathematical Finance, 15(3).

Kanga, W-Y., \& Poshakwale, S. (2019). A new approach to optimal capital allocation for RORAC maximization in banks. Journal of Banking and Finance, 106.

Klingebiel, R., \& Rammer, C. (2013). Resource Allocation Strategy for innovation Portfolio Management. Strategic Management Journal, 35(2). https://doi.org/10.1002/smj.2107

Maume-Deschamps, V., \& et al.. (2015). A risk management approach to capital allocation. Papers 1506.04125, arXiv.org, 79(1). https://doi.org/10.1111/j.1539-6975.2011.01408.x

Merton, R., \& Perold, A. (1993). Theory of Risk Capital in Financial Firms. Journal of Applied Corporate Finance, 6, 16-32.

Merton, R., \& Perold, A. F. (1993). Theory of Risk Capital in FinancialFirms. Journal of Applied Corporate Finance, 6(3). https://doi.org/10.1111/j.1745-6622.1993.tb00231.x

Nguyen, T. T., \& et al.. (2015). Fuzzy Portfolio Allocation Models through a New Risk Measure and Fuzzy Sharpe Ratio. IEEE Transactions on Fuzzy Systems, 23(3). https://doi.org/10.1109/TFUZZ.2014.2321614

Rigamonti, A., \& Weissensteiner, A. (2020). Asset allocation under predictability and parameter uncertainty using LASSO. Computational Management Science, 17, 179-201. https://doi.org/10.1007/s10287-020-00367-4

Sherris, M. (2006). Solvency, Capital Allocation, and Fair RateofReturn in insurance. The Journal of Risk and Insurance, 73(1), 71-96.

Todinov, M. T. (2014). Optimal allocation of limited resources among discrete risk-reduction options. Artificial Intelligence Research, 3(4).

Turnbull, S. M. (2000). Capital Allocation and Risk Performance Measurement in a Financial Institution. Financial Markets Institution and Instrument, 9(5). https://doi.org/10.1111/1468-0416.00039

Weiss, M. A. (2010). Systemic Risk and the U.S. Insurance Sector. Retrieved from http://www.naic.org/documents/cipr_weiss_systemic_risk_100223.pdf

Yow, S., \& Sherris, M. (2007). Enterprise Risk Management, Insurer Pricing, and Capital Allocation. Retrieved from https://www.researchgate.net/publication/40969901

\section{Copyrights}

Copyright for this article is retained by the author(s), with first publication rights granted to the journal.

This is an open-access article distributed under the terms and conditions of the Creative Commons Attribution license (http://creativecommons.org/licenses/by/4.0/). 